\title{
1. Capturing the dynamism of fairness: a common law perspective
}

\section{Poorna Mysoor ${ }^{1}$}

Statutory limitations and exceptions are often put forward as the balancing mechanism of copyright law. As provisions that cater to the interests of various stakeholders, these are meant to bring fairness into the copyright system. However, statutory limitations and exceptions are steeped in formalism, which is manifest in three important ways. First, formalism dictates that these limitations and exceptions are statutory meaning that the law only recognises the legislature as the repository of powers to limit or exclude copyright protection. Secondly, formalism requires that these limitations and exceptions are exhaustively enumerated in the statute. Thus, the role of the courts is limited to interpreting the express language of the statutory limitations and exceptions so enumerated. Thirdly, the structure of the formalism is such that copyright protection is the norm from which these limitations and exceptions are then carved out, addressing specific instances of permitted use of a copyright. As exceptions to the rule, in other words, these limitations and exceptions are required to be interpreted narrowly, ${ }^{2}$ thus further constraining the role of the courts. This set-up makes one wonder whether formalism can achieve fairness.

Statutory limitations and exceptions include sweeping generalisations as to the circumstances when it would be fair not to enforce use restrictions based on copyright. However, fairness which is a function of time and space, is a dynamic concept. Along the axis of time over the last 300 years, the socio-cultural and technological milieu within which

1 The author is deeply grateful to Professor Graeme Dinwoodie for his comments on an earlier draft. The author is also grateful for the comments received from Professor Sam Ricketson at the ATRIP Annual Meeting, 2018.

2 Case C-5/08 Infopaq International A/S v Danske Dagblades Forening [2009] ECR I-6569 [56]-[57]. 
copyright law operates has undergone and continues to undergo tremendous change. Spatially, copyright law has begun to operate upon an expanding array of subject matter, covering a wider variety of industries and markets. Given this, how is fairness meant to fit within the four corners of the statutory limitations and exceptions? The formalism of copyright law struggles to adapt to this dynamism. To begin with, an exhaustive list of statutory limitations and exceptions is an anathema to dynamism. The legislature keeping pace with the changing times by enacting new statutory limitations and exceptions is a time-consuming process, aggravated by political influences. One might argue that the advantage of formalism is certainty of the law. However, of what value is certainty of the law if the result of its application is unfair?

This chapter argues that the dynamism of fairness is better captured by a court, which can take into account the changing times and the circumstances on a case-by-case basis. In other words, the courts can assess fairness as a function of time and space. To illustrate this point, this chapter looks to common law tradition given its centrality of the role of judges. In this context, some readers might think of the US fair use doctrine or fair dealing as examples of a less formalistic role of the courts, although in their application the courts often follow a fairly formal analysis of the applicable criteria. But this chapter examines the much less examined yet facially more open common law power of the judges to prevent or restrict the enforcement of copyright on the grounds of public interest or otherwise, which is preserved under s 171(3) of the UK Copyright Designs and Patents Act, 1988 (CDPA). This provision is an acknowledgement that there may be a case where the public interest may lie outside the framework of statutory limitations and exceptions. And on the premise that achieving the public interest in such cases achieves fairness, the exercise of this power by the judges can capture the dynamism of fairness. In this sense, public interest is used almost as a proxy for fairness. This chapter reviews the UK's experience of its judges exercising this power under the broad heading of the public interest defence to copyright infringement.

With the imminence of Brexit, the role and relevance of common law to the EU is a big question. However, it helps to examine how this common law power has evolved and been exercised in the UK and more specifically, what it has meant to arrive at a fair outcome when the power lies with the judges, rather than the legislators. Accordingly, this chapter begins by exploring the contextual background of s 171(3), which throws light on the open-ended nature of this power. It examines the consequences of the open-ended nature of the power in the light of the UK's international treaty obligations and the Information Society Directive. It 
analyses whether subjecting this power to the three-step test will ensure a deeper compliance with these obligations, and whether the courts are better placed to apply this test meaningfully on a case-by-case basis. It goes on to show the potential wingspan of this power, critically evaluating significant cases where the courts have been asked to exercise this power. It assesses whether a closer compliance with the three-step test may have borne better results in some cases. It concludes by examining what this common law power can inspire within the EU copyright law, especially when a fair outcome has become more and more elusive with changes in technology.

\section{THE CONTEXT OF SECTION 171(3) AND COURTS' POWER}

One may wonder what the role of a 'statutory' provision such as s 171(3) CDPA is when the power it grants the courts is meant to emanate from common law. Let us begin with the actual provision itself. Section 171 bears the sub-heading 'Rights and privileges under other enactments or the common law', and sub-s 3 states: 'Nothing in this Part affects any rule of law preventing or restricting the enforcement of copyright, on grounds of public interest or otherwise.' The provision appears under the chapter 'Transitional Provisions and Savings'. Therefore, from the context in which this provision appears, one can deduce that if there was a rule of law originating in common law conferring powers on the courts to prevent or restrict the enforcement of copyright, then such rule is saved or preserved under this provision.

The rule should, therefore, have existed at common law before the enactment of the CDPA. For this, a peek into the legislative history of the CDPA might help in demonstrating what might have driven the inclusion of this provision. In the debates, Lord Morton wanted to introduce a provision stating simply that '[c]opyright is not infringed by anything done in the public interest', before incorporating the provisions on fair dealing. He acknowledged that the courts already exercised the power to restrict copyright in the public interest under certain circumstances but added that the purpose of this provision was to confirm it in the statute in order to avoid ambiguity. In the debate that ensued, the peers were in agreement on the existence of the power but had disagreements as to the need for a statutory recognition of a public interest defence, when the courts are perfectly capable of carving it out themselves. The broad and 
general wording of the proposed provision was also questioned. ${ }^{3}$ In the subsequent reading, Lord Morton placed it in the chapter that dealt with restating the existing copyright law. Lord Lloyd supported it on the basis that other forms of intellectual property, such as trademarks, do provide a public interest defence. In the discussion that ensued, the peers were still not convinced that a public interest defence needed to be restated, although Lord Morton insisted that if not restated, it might be understood as the power having been taken away. ${ }^{4}$

Eventually the government proposed the provision in the form that it exists today. There was a debate as to whether the aspects that make up public interest should be enumerated - such as 'a matter of grave public concern or the existence of crime, fraud, abuse of authority, neglect in the performance of official duty or other misconduct'. ${ }^{5}$ However, such enumeration was rejected on the basis that any statutory provision embodying public interest should only continue the effect of the case law 'without attempting to codify it, thus leaving the law on this matter where it has always been, in the hands of the courts'. 6 Thus, the open-endedness of the common law power was preserved, ensuring its full potential to be realised by the judges.

This common law power challenges formalism in every respect. It is not statutory in origin, but judicial. The criteria to prevent or restrict copyright enforcement are not enumerated or exhaustive, but open-ended within the broader concept of public interest. Since public interest is a value as important as copyright, there is no underlying acceptance of copyright enforcement being a norm and public interest an exception. This should make this common law power a sensible mechanism to achieve fairness in a case. However, the power does limit or exclude copyright enforcement, albeit judicially. Since in its effect it behaves like a statutory limitation or exception, a question arises as to whether this power must also be regulated the same way and be subject to the same constraints. Before s 171(3) was enacted, the courts had held that this power of the courts is different from statutory limitations and exceptions, and that it is a general principle of common law not limited to copyright. ${ }^{7}$ After its enactment, Aldous LJ noted that the statutory limitations and exceptions enumerated in Chapter III of Part I embodied the extent of public interest that can override copyright. And since s 171(3) exists

\footnotetext{
HL Deb 08 December 1987, vol 491, cols 75-8.

HL Deb 23 February 1988, vol 493, cols 1162-4.

HL Deb 29 March 1988, vol 495, cols 630-1.

ibid cols 632-5.

Beloff v Pressdram [1973] FSR 33, 56.
} 
outside this chapter, the power must arise from the inherent jurisdiction of the courts to refuse to let its process be used under certain circumstances. ${ }^{8}$ This decision has led to an argument that s 171(3) does not qualify as a statutory limitation or exception but is an expression of a more general principle. ${ }^{9}$ Thus far, there is no consensus on whether the common law power is to be regarded akin to a statutory limitation or exception. ${ }^{10}$

\section{COMPATIBILITY WITH INTERNATIONAL AND EU OBLIGATIONS}

To the extent that a court's exercise of this power can limit or exclude copyright enforcement and its basis arises from an open-ended concept of public interest, the compatibility of this power with the international treaties and the Information Society Directive must be examined. In some cases the common law power is used to deny equitable relief (of injunction) against enforcement of copyright. ${ }^{11}$ To this extent, one may argue that it is not a defence, but only a refusal of remedy. The usefulness of the common law powers in denying injunction cannot be denied, as the discussion below will elucidate. ${ }^{12}$ However, the dominant discussion of the common law powers has been as a defence of public interest. ${ }^{13}$

\subsection{Compatibility with the Berne Convention}

There is a UK Court of Appeal authority that claims that neither the Berne Convention (BC), nor the EU Directives recognise a general public interest defence, and therefore the common law power might go against

\footnotetext{
8 Hyde Park Residence Ltd v Yelland [2000] EWCA Civ 37 [43]-[44].

9 Jonathan Griffiths, 'Copyright Law After Ashdown - Time to Deal Fairly with the Public' [2002] IPQ 240, 264.

10 Robert Burrell, 'Defending the Public Interest' [2000] EIPR 394, 403; Robert Burrell and Alison Coleman, Copyright Exceptions: The Digital Impact (CUP 2005) 81; Alexandra Sims, 'The Public Interest Defence in Copyright Law: Myth or Reality?' [2006] EIPR 335, 338-9.

11 A-G v Guardian Newspapers No. 2 [1990] 1 AC 109, 294, per Lord Jauncey.

12 See discussions of Beggars Banquet v Carlton [1993] EMLR 349 and SCI $v$ Channel Four [1999] EMLR 83 below.

13 Hyde Park Residence Ltd v Yelland [2000] EWCA Civ 37 [45] where Aldous LJ does accept the characterisation of the common law power as a denial of equitable remedy, but a significant part of his judgment refers to it as the public interest defence.
} 
the UK's international obligations. ${ }^{14}$ However, Burrell argues in response that the common law power is in compliance with the ordre public provision under Article 17 and the three-step test under Article 9(2), BC. ${ }^{15}$ Article 17 empowers a Union member's government (including all competent authorities) to control or prohibit the circulation of a work as it finds necessary. The underlying principle is ordre public, a notion rooted in a state's ability to control circulation of copyright works (not necessarily depriving copyright enforcement) based on morality and other socio-cultural values. ${ }^{16}$ Although compatibility with Article 17 does not appear to be an issue as the case law below shows, confining public interest to ordre public under Article 17 is a reductionist view, as public interest can be a broader concept than protecting morality or values.

As for compliance with the three-step test under Article 9(2), not all commentators agree that an open-ended provision allowing the courts to define 'certain special cases' complies with Article 9(2). ${ }^{17}$ However, fair use under s 107 of the US Copyright Act 1976 is an open-ended exception. The accession of the US to the BC (through Article 9(1) of the Agreement on Trade-Related Aspects of Intellectual Property Rights (TRIPS)) was premised on the acceptability of fair use under the BC. ${ }^{18}$ The fair use provision has remained unchallenged at the international level in the years since then. ${ }^{19}$ Further, the fair dealing provision is also open ended to the limited extent of allowing the courts to decide on a case-by-case basis what is 'fair'. Fair dealing existed under s 6 of the UK Copyright Act 1956, which did not prevent the UK's accession to the Stockholm Act of 1967. This provision, too, now under s 30 CDPA, has never been challenged for violating Article 9(2). Therefore, the openendedness of the common law power may not violate the three-step test. The phraseology of Article 9(2) addresses the legislatures of the Union members. To the extent that the three-step test is not implemented expressly in the UK national legislation, the UK courts are not obliged to

\footnotetext{
14 Hyde Park Residence Ltd v Yelland [2000] EWCA Civ 37 [55].

15 Burrell (n 10) 396.

16 Sam Ricketson and Jane Ginsburg, International Copyright and Neighbouring Rights (vol 1, OUP 2005) [13.88].

17 Sam Ricketson, The Three-step Test, Deemed Quantities, Libraries and Closed Exceptions (Centre for Copyright Studies 2002) 31, 147-54.

18 Pamela Samuelson, 'Challenges for the WIPO and the TRIPS Council in Regulating Intellectual Property Rights in the Information Age' [1999] EIPR 578, 582-3.

19 Martin Senftleben, Copyright, Limitations and the Three-Step Test (Kluwer Law 2004) $162-8$ as to why fair use is compliant with the three-step test.
} 
recognise the direct application of Article 9(2) BC. However, the courts may still consider treaty provisions to interpret the law. ${ }^{20}$

In this context, since the common law power is potentially quite broad, in order to ensure compliance with the international obligations in the exercise of this power, it is possible to put forward the three-step test under Article 9(2) as a guiding framework.

\subsection{Compatibility with the Information Society Directive}

Given that the impact of Brexit on the CDPA is uncertain, it is worth examining the compatibility of the common law power with the Infosoc Directive. ${ }^{21}$ The common law power was already in existence when legislation was passed adopting the provisions of the Infosoc Directive. Therefore, guidance may be sought from recital 31 Infosoc Directive, which states that the existing statutory limitations and exceptions should be 'reassessed in the new electronic environment'. The recital goes on to say that any differences in the existing limitations and exceptions within the laws of the member states can have a negative effect on the internal market, requiring these to be defined more harmoniously, with a view to achieving a smooth functioning of the internal market. As such, commentators in the UK are of the view that post Infosoc Directive, the scope of the common law powers is restricted. They argue that the only extent to which the common law power survives is (i) where the CDPA has not yet transposed an exception from the Directive; (ii) where, under Article 5(3)(o) Infosoc Directive, a member state may provide for analogue use in certain cases of minor importance where the statutory limitations or exceptions to this effect already exist; and (iii) to enforce freedom of expression. ${ }^{22}$

Burrell and Coleman argue that s 171(3) may be read into Article $5(3)(e)$, which provides for an exception to protect public security and to ensure performance of official duties. However, they acknowledge that

20 J H Rayner (Mincing Lane) Ltd v Department of Trade and Industry [1990] 2 AC 418, 499-501.

21 Directive 2001/29/EC of the European Parliament and of the Council of 22 May 2001 on the harmonisation of certain aspects of copyright and related rights in the information society, OJ L 167, 22/06/2001 P. 0010-0019.

22 Hugh Ian Lang Laddie, Peter Prescott and Mary Vitoria, Laddie, Prescott and Vitoria, The Modern Law of Copyright and Designs (4th edn, vol 1, Lexis Nexis 2011) [21.22]; Gillian Davies, Nicholas Caddick and Gwilym Harbottle, Copinger and Skone Janes on Copyright (17th edn, Sweet \& Maxwell 2016) [21-108]; Lionel Bently and Brad Sherman, Intellectual Property Law (4th edn, OUP 2014) 248. 
public security is a slippery concept, stating that freedom of expression under the European Convention on Human Rights (ECHR) may be relied on in addition. They also cite Article 9, Infosoc Directive, which preserves national laws on confidentiality. They further argue that the common law powers may act as the equivalent of provisions that prohibit abuse of rights in other EU jurisdictions. ${ }^{23}$ The common law power is broad enough to encompass free speech, public security and confidentiality, as discussed below. Abuse of the process might capture many of the public interest cases as will be discussed below, but it does not capture the full essence of public interest. If the exercise of the power does not negatively affect the internal market, there is no reason why the common law powers cannot be broader.

Recital 32 of the Infosoc Directive declares the statutory limitations and exceptions enumerated in the Infosoc Directive to be exhaustive. While implementing the Infosoc Directive, the UK under the Copyright and Related Rights Regulations 2003 (SI 2003/2498) did not enact any provision that prevented the courts from going beyond the enumerated limitations and exceptions in the Directive, nor did the Regulations amend s 171(3) to restrict the courts' powers. Since the Directive does not directly address the courts, one may argue that there is no direct conflict between the pre-existing law and the law implementing the Directive, and therefore there is no implied repeal. ${ }^{24}$ However, the Infosoc Directive will have an indirect effect on the courts of the member states because the Court of Justice of the European Union (CJEU) has held that a national court must interpret a provision as far as possible in the light of the wording and the purpose of the Directive, in order to achieve the result pursued by the Directive. ${ }^{25}$

Of particular significance, however, is recital 3, which declares public interest as one of 'the fundamental principles of law' together with intellectual property and freedom of expression. As such, a judge exercising her powers in the public interest in a case will be in compliance with one of the fundamental principles of EU law and therefore cannot be regarded as causing disharmony in the internal market. Therefore, this is an additional reason why recitals 3 and 31 require harmonious construction of pre-existing limitations and exceptions.

\footnotetext{
23 Burrell and Coleman (n 10) 107-8.

24 A W Bradley, Keith Ewing and Christopher Knight, Constitutional \& Administrative Law (16th edn, Pearson 2015) 56.

25 Case 106/89 Marleasing SA v La Comercial Internacional de Alimentacion SA [1990] ECR I-4135, [8].
} 
In order to exercise the common law power harmoniously with the Directive and reduce any possible negative effects on the internal market, courts may apply the three-step test under Article 5(4) in arriving at their decision. This should not be problematic, as the courts are in the best position to apply the test, as argued in the section below.

\subsection{The Three-step Test as a Guideline}

Even if Brexit means that the UK will not have to interpret its laws compatibly with some or all of the EU Directives, the UK will still be subject to its international obligations, including under the BC. Therefore, using the three-step test as a guideline for the exercise of the common law power would still be appropriate. This should not pose any challenges since the courts are in the best position to be the addressees of the three-step test as they can utilise the open-ended abstract criteria of the test to their fullest potential, on a case-by-case basis. Given that the courts are in the forefront of dealing with the current challenges, arming the courts with the application of the test that can meet the challenges presented by modern copyright law is a pragmatic option. ${ }^{26}$

There is a belief that the historical origins required the test to be vague, making it unsuitable as a guideline to the courts. ${ }^{27}$ However, as the decision of the World Trade Organization (WTO) Panel on the US Copyright Act 1976, s 110(5)(b) demonstrates, it is possible to use the flexible criteria of the three-step test to guide a court's exercise of this power.

\subsubsection{Certain special cases}

The Panel interpreted 'certain' to mean 'clearly defined', and 'special cases' to mean 'limited in its field of application or exceptional in its scope' and 'narrow in both qualitative and quantitative sense'. However, importantly, it held that there was no need 'to identify explicitly each and every possible situation to which the exception could apply, provided that the scope of the exception was known and particularised'.28 Thus, the threshold for identifying a special case is low but provides sufficient

\footnotetext{
26 Huaiwen He, 'Seeking a Balanced Interpretation of the Three-step Test' [2009] IIC 274, 306.

27 Jonathan Griffiths, 'The "Three-step Test" in European Copyright Law Problems and Solutions' [2009] IPQ 428, 429-30; Kamiel Koelman, 'Fixing the Three-step Test' [2006] 28 EIPR 407, 408.

28 Panel Rep. of 15 June 2000, United States - Article 110(5) of the US Copyright Act, WT/DS160/R [6.108]-[6.109], [6.145] (WTO Panel).
} 
room for the courts to define a 'certain special case', based on the facts, circumstances and issues presented by each case. As Geiger, Gervais and Senftleben rightly point out: ${ }^{29}$ 'With every court decision, a further "special case" becomes known, particularized and thus "certain" in the sense of the three-step test. A sufficient degree of legal certainty thus may follow from established case law ...' Therefore, a court will have no difficulty satisfying this criterion.

\subsubsection{Do not conflict with the normal exploitation of the work}

The Panel held 'normal exploitation' to involve copyright owners extracting economic value from their rights. The forms of exploitation include those that "currently generate income for the rightholders as well as those which, in all probability, are likely to be of considerable importance in the future' ${ }^{30}$ On the face of it, this interpretation appears to have a purely economic focus, which is understandable in the context of a trade-based dispute, though this has led to much controversy in understanding the overall normative value of the test. However, the Panel does recognise that the word 'normal' has both empirical and normative meaning. The Panel favoured the empirical (and economic) considerations since the exception being considered, namely exempting certain commercial establishments using home-style recording devices from payment of royalties for the music they played, did not require the kind of normative balancing that would be required for, say, a case involving a library or an educational establishment. The Panel does say that a normative meaning 'includes, inter alia, a dynamic element capable of taking into account technological and market developments' ${ }^{31}$ Therefore, there should be no reason to regard the outcome of the Panel's decision as the only way 'normal' can be interpreted in all circumstances. ${ }^{32}$ There is strong support for incorporating non-economic considerations such as freedom of expression, research and scholarship within a normative framework when assessing normal exploitation. ${ }^{33}$ Even if economic interpretation is to be followed, a conflict with the normal exploitation

29 Christophe Geiger, Daniel Gervais and Martin Senftleben, 'The Three-Step Test Revisited: How to Use the Test's Flexibility in National Copyright Law' (2013) PIJIP Research Paper no. 2013-04, p 33.

30 WTO Panel (n 28) [6.165], [6.180] and [6.183].

31 ibid [6.166], [6.178].

32 Graeme Dinwoodie, 'The Development and Incorporation of International Norms in the formation of Copyright Law' (2001) 62 Ohio State Law Journal 733, 756.

33 Ricketson and Ginsburg (n 16) [13.20]-[13.22]. 
should only be regarded as arising where copyright owner is deprived of an extensive share of her potential market. ${ }^{34}$

\subsubsection{Do not unreasonably interfere with the legitimate interests of the right holder}

The Panel interpreted 'legitimate' to mean lawful from both a positivist and a normative perspective. Although in the exception being considered, the Panel focused only on the economic interests, the Panel clarified that legitimate interests are not necessarily limited to the economic value. Importantly, the Panel held that all statutory limitations and exceptions cause prejudice to the exclusive rights, and therefore only those that are unreasonable must be considered. ${ }^{35}$ Commentators point out that not all interests, but only legitimate interests need to be considered, which means that interests that are permitted by law must be balanced with those that are legitimate at a normative level. They argue that 'reasonable' means proportionate or within reason or is not unreasonable and may impose conditions while balancing. ${ }^{36}$

$\mathrm{Be}$ it the assessment of the legitimacy or the proportionality of prejudice caused, courts are in a good position to conduct the balancing exercise as they can do so on a case-by-case basis and not rely on vast generalisations, which the legislature must do. As confirmed by the Panel, in assessing what is a legitimate interest of a copyright owner, a holistic approach beyond the economic interests of the copyright owner may be taken. One may observe here that in the version of the test contained in the TRIPS Agreement, such as Article 30 in relation to patents, the interests of third parties are specifically mentioned.

Having thus established that the three-step test can be a valuable guideline for a court in exercising its common law powers to achieve a fair and balanced outcome, it helps now to review the case law to shed light on the type of cases which have made the courts rise to the occasion.

\section{COURTS' READING OF PUBLIC INTEREST TO ACHIEVE FAIRNESS}

The UK courts have historically exercised their power to restrict or prevent the enforcement of copyright in the public interest. This power

\footnotetext{
34 Griffiths (n 27) 457.

35 WTO Panel (n 29) [6.224]-[6.229].

36 Ricketson and Ginsburg (n 16) [13.24]-[13.26].
} 
continued after the CDPA was enacted and was acknowledged even after the Infosoc Directive was transposed. This section discusses example cases to demonstrate how public interest manifests in different ways. The section below also addresses how the courts do sometimes reach an incorrect conclusion and how the three-step test could have guided these cases better.

Historically courts have used copyright on occasion to restrict copyright enforcement in works of objectionable content. ${ }^{37}$ An example from 20th century is Glyn v Weston Feature Film Co, concerning a work of fiction which recounted the clandestine affair of the queen of a fictitious country. ${ }^{38}$ The issue was the unauthorised use of the author's work by the defendant in its film. Although the Court held that there was no such unauthorised use, it held obiter that 'copyright cannot exist in a work of a tendency so grossly immoral' ${ }^{39}$ To this extent, one can notice public interest manifesting in the form of ordre public that spoke more to the values of those times.

In addition to ordre public, public interest can also capture public security. Attorney General v Guardian Newspapers (Spycatcher) concerned a book on the alleged irregularities and practices of MI5 by an ex-employee. The Attorney General sought to prevent its publication on the grounds of national security, among others. ${ }^{40}$ The House of Lords granted the injunction preventing its publication. Relying on Glyn, Lord Jauncey held that no court in the UK would have enforced copyright in the book, and that anyone could copy the book in whole or in part without fearing infringement. ${ }^{41}$

Another distinct line of cases are those requiring disclosure of information in the public interest, which arose first in the context of confidentiality. If confidentiality only extends to information, no copyright would subsist in it. However, given the continued lowering of the threshold for originality, the courts have realised that the same information in which confidentiality is claimed could also be protected by copyright. In most cases, the existence of copyright was purely incidental and there was little or no prospect of the copyright work in question being exploited independently by the author. This explains why courts

\footnotetext{
37 Stockdale v Onwhyn (1826) 108 ER 65, where copyright was denied in an allegedly libellous novel.

38 [1916] 1 Ch 261.

39 ibid 269.

40 [1990] 1 AC 109, 116, 120-3.

41 ibid 294.
} 
may not have wished for a copyright infringement claim to come in the way of a genuine need for the disclosure of confidential information. ${ }^{42}$

In Beloff $v$ Pressdram Limited ${ }^{43}$ an internal memorandum written by the plaintiff, a correspondent of a newspaper, was reproduced and published by the defendant magazine. ${ }^{44}$ The memorandum contained discussions with cabinet ministers as to who should succeed the prime minister in the event of his accidental death. The plaintiff raised both breach of confidence and copyright infringement. The defendant raised public interest as a defence both to confidentiality and copyright infringement, in addition to fair dealing. Given the minimal literary quality of the memorandum, the Court acknowledged that it was not a genuine case of copyright infringement. The confidential nature of the memorandum appeared stronger since it named the cabinet ministers as the source of the plaintiff's information. The Court treated the case as concerning confidentiality, couched in terms of copyright infringement. Based on prior authority on confidentiality, it concluded that public interest would come into play only if there was a 'disclosure of iniquity'. Since the memorandum did not disclose any iniquity or misdeed on anyone's part that needed to be covered up, the Court held that no public interest would be served in its disclosure. ${ }^{45}$ This decision saw the same standards of public interest in confidentiality case being applied to copyright cases.

An opportunity to broaden the scope of public interest in copyright cases arose in Lion Laboratories Ltd $v$ Evans, ${ }^{46}$ where the plaintiff carried on the business of selling Intoximeters, which were instruments used by the police for measuring intoxication by alcohol for road safety. Two of the defendants, who were ex-employees of the plaintiff, provided certain internal correspondence, indicating the faulty calibration of Intoximeters giving incorrect results, to the defendant newspapers for publication. The plaintiff sued them for breach of confidence and copyright infringement. ${ }^{47}$ There was no dispute as to the confidentiality of the correspondence, nor as to the plaintiff's ownership of copyright in it. The trial judge granted an injunction restraining the defendant newspapers from publishing, against which the defendants appealed.

At the Court of Appeal, a big part of Stephenson LJ's judgment is devoted to establishing the existence of public interest as a defence to

\footnotetext{
42 Burrell (n 10) 395-6.

43 [1973] FSR 33.

44 ibid 35.

45 ibid 54-8.

46 [1985] QB 526, 550.

47 ibid 532-3.
} 
confidentiality. He found that given the plaintiff's monopoly in supplying these instruments and the evidentiary value of their readings in criminal convictions, the public had a genuine interest in knowing the fallibility of these instruments. ${ }^{48}$ Griffiths LJ not only accepted that the public interest defence extended also to copyright infringement, he went on to clarify that there was no requirement of iniquity, misdeed or criminality before a public interest defence could be established. ${ }^{49}$ In holding that iniquity, misdeed or criminality was not a precondition to requiring disclosure in the public interest, Lion showed foresight in acknowledging that public interest could arise in broader circumstances.

Moving away from confidentiality, in the cases discussed below it would appear that the Court's focus may have been to prevent abuse of process, but it is clear that the courts were upholding a much larger public interest. Although these cases only concern interim remedies, Burrell argues that 'they are part of a wider picture which shows that the courts were clearly moving toward the recognition of such a defence'.50

One such case was Beggars Banquet v Carlton, where the plaintiff was a record company which had organised an all-night dance party, colloquially called a 'rave'. The plaintiff entered into an agreement with the second defendant, Spidercom, a film production company, to create a film about the rave. During the event, a teenage boy died due to the consumption of the prohibited drug Ecstasy. ${ }^{51}$ The film was never completed and Spidercom was not paid in full for its services. Spidercom approached the first defendant, Carlton, a television channel, and produced a documentary on the dangers of rave parties and the death of the teenager. The plaintiff applied to the Court for an interlocutory injunction, among other claims, to prevent the broadcast of the documentary on the grounds of copyright infringement. ${ }^{52}$ The defendants raised public interest as one of the defences to the plaintiff's assertion of copyright.

Although a significant issue was the ownership of the footage shot by Spidercom, Warren J concluded that there was an arguable case that the plaintiff was the sole or joint owner of the footage with Spidercom. As regards the injunction restraining the broadcast of the documentary, Warren $\mathrm{J}$ acknowledged the defence of public interest, relying on Lion, among others, as pointing to an 'emerging jurisdiction'. He denied the injunction due to the public interest in conveying with 'vivid and telling'

\footnotetext{
48 ibid 539.

49 ibid 550.

50 Burrell (n 10) 402.

51 [1993] EMLR 349, 353-6.

52 ibid 359-60.
} 
images the dangers of Ecstasy and the goings-on at rave parties. ${ }^{53} \mathrm{He}$ did this by reading public interest into the balancing exercise required for the grant of interim injunctions. He noted that any harm to the plaintiff is likely to be outweighed by the harm to the public interest if the broadcast is prevented.

In Service Corporation International v Channel Four, an employee of a funeral services home conducted an undercover operation for the defendant television channel to disclose to the public the disrespectful and abusive treatment of corpses by the plaintiff. ${ }^{54}$ The plaintiff (SCI) sought a temporary injunction on the basis, inter alia, of copyright infringement. The defendant raised the defence of public interest. ${ }^{55}$ Lightman J held that SCI did not have an arguable case on copyright ownership since the employee had produced the film outside the course of his employment, without breaching any fiduciary duty. However, even if SCI could show its entitlement to copyright, he held that the defendants had an arguable case that the broadcast of the programme was in the public interest. He held that the defendant's film revealed 'a scandalous state of affairs' and supports the defendants' case that the funeral home industry should be regulated as a matter of 'substantial public interest', factoring in public interest in the balancing exercise to refuse the injunction. 56

The Court's perception of public interest and its ability to achieve fairness took a significant step back with the following two Court of Appeal decisions, which remain the highest and most recent authority on this point. In Hyde Park Residence $v$ Yelland ${ }^{57}$ the plaintiff managed the security of Villa Windsor, a place visited by Princess Diana and Dodi Fayed on the day before their death in a car accident. Certain still photographs of the Princess and Fayed derived from the claimant's security cameras during their visit to the villa had been given away by the claimant's employee to the defendant newspaper without permission, allegedly to expose the falsehood surrounding their death. The plaintiff alleged copyright infringement but not breach of confidentiality. ${ }^{58}$ The defendant raised the defence of fair dealing and public interest.

Jacob $\mathrm{J}$ upheld the claim of fair dealing. As to the public interest defence, while recognising the close connection the defence has with

\footnotetext{
53 ibid 364, 371-2.

54 [1999] EMLR 83.

55 ibid 86-8.

56 ibid 90-2.

57 [1999] EWHC Patents 247.

58 ibid [1]-[8].
} 
confidentiality cases, he clarified that the defence is narrow and applies only in cases where no right-thinking person would conclude otherwise, and that the disclosure must be proportionate to the public interest. ${ }^{59}$ When the plaintiff appealed, in the Court of Appeal, Aldous LJ acknowledged the existence of the defence of public interest to copyright infringement but held it to be limited to cases where enforcement of copyright would 'offend against the policy of the law' ${ }^{60}$ While admitting that the circumstances under which the public interest defence would come into play are not capable of definition, Aldous LJ still went on to enumerate these circumstances thus: where the copyright work is immoral, scandalous or contrary to family life, or is injurious to public life, public health and safety or the administration of justice. ${ }^{61}$ Mance LJ disagreed and held that the public interest defence is not capable of precise categorisation. ${ }^{62}$ Stuart-Smith LJ gave a one-line judgment agreeing with the Court. On the facts, the Court was unanimous in holding that no defence of public interest (or of fair dealing) was established. ${ }^{63}$

This decision is problematic: first, the categorisation of public interest is unjustified. There is a reason why s 171(3) is broadly worded - to give courts the maximum flexibility in assessing each case on its own facts. The legislative history also supports this. Secondly, and substantively, the categories are clearly quite narrow. They represent only the line of cases captured above, where copyright enforcement is refused because the content is objectionable, and not because the public should benefit from its disclosure. Thirdly, it pays no heed to the High Court decisions that had already recognised the public interest defence, independent of a claim in confidentiality, such as in Beggars and SCI. ${ }^{64}$ Instead, as we will see below, this case set a bad precedent. The decision drew much criticism also for not appreciating that the public interest in exposing the lies surrounding the death of 'a future sovereign's mother' outweighed the copyright protection in the photographs, which, in any event, were captured due to no exercise of human creativity. ${ }^{65}$

The combined question of confidentiality and copyright arose again in Ashdown $v$ Telegraph Group Limited. ${ }^{66}$ The plaintiff was a leader of a

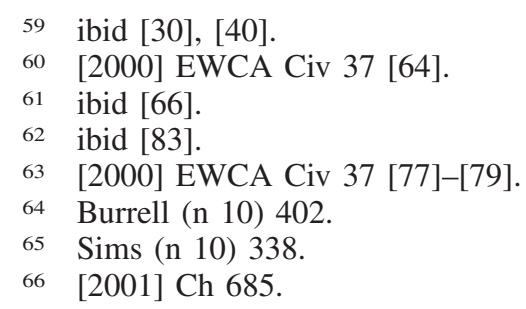


political party and had authored the minutes of a confidential meeting with the then prime minister of the UK. He was in the habit of keeping diaries of his political career, which he later wanted to publish as a book. He had disclosed the minutes to a group of journalists and publishers for this purpose, in strict confidence. However, the minutes were leaked and the defendant newspaper carried a feature, quoting extensively from the minutes. The plaintiff sued for breach of confidence and copyright infringement, claiming an injunction and damages. The defendant put forward a defence of fair dealing and public interest. ${ }^{67}$

Denying the defendants a defence in both fair dealing and public interest, the High Court granted the plaintiff summary judgment. As to the public interest defence, the Court regarded Aldous LJ's enumeration in Yelland of circumstances under which the public interest defence could be exercised as the majority view and a view binding on the Court. It held that the facts of the case did not fall within any of those categories. ${ }^{68}$ This decision is a clear example of the narrowing of the defence caused by Aldous LJ's judgment.

The defendants appealed and the Court of Appeal held that the High Court's strict adherence to the list of circumstances enumerated by Aldous LJ was unjustified as Mance LJ had disagreed with him and Stuart-Smith LJ had not expressed a specific opinion. As such, the Court went on to regard Lion as the authority on the point. Upon analysing the judgment, it held that two of the three judges in Lion had recognised a defence of public interest even when there was no moral turpitude. The Court therefore endorsed Mance LJ's views that the circumstances in which the public interest defence can be claimed are not capable of precise enumeration. ${ }^{69}$ This decision would have brought back, to some extent, the flexibility and breadth of s 171(3). But it held that the fair dealing defence under s 30 CDPA would "normally afford the court all the scope' it needed to reflect the public interest in freedom of expression and therefore there would be no need to consider separately the public interest defence under s 171(3). ${ }^{70}$ Although it held that with the passing of the Human Rights Act 1998 (HRA) there is a clear public interest in protecting free speech, it regarded such cases to be very rare. ${ }^{71}$

On the facts, the Court concluded that the defence of public interest was not made out. The Court observed that there was no justification for

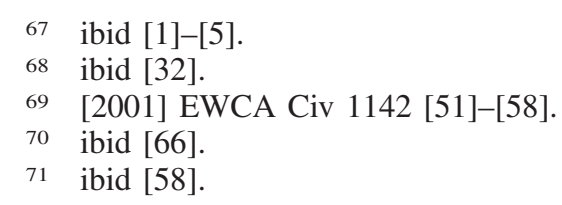


the defendant to have used the exact words of the minutes. It could have used its own words to describe the contents of the minutes, as relevant, especially since there were other newspapers which reported the same event without copying extensively from the minutes. ${ }^{72}$ This interpretation is too restrictive. The cases which do not come under fair dealing for not being criticism, review or reporting current events, and where the authenticity of journalism demands verbatim quoting, are exactly the type of cases which s 171(3) must save from infringement.

The overriding theme in the above cases is the disclosure of copyright work in the public interest. The public interest is by no means confined to the disclosure of copyright works, free speech or press freedom. The line of cases below on the spare parts exception shows how broad the application of public interest can be. A significant authority is British Leyland Motor Company Ltd v Armstrong Patent Co Ltd, where the plaintiff (BL), a car manufacturer, had asserted its claim to copyright in the design of the spare parts and had compelled many spare parts manufacturers to become licensees and pay royalties on sales of spare parts. However, the defendant (Armstrong) had always resisted becoming a licensee. BL claimed that Armstrong had reverse engineered and copied BL's exhaust pipes, thereby infringing its copyright in the design of the exhaust pipe. ${ }^{73}$ The question was whether there was anything in the law to prevent $\mathrm{BL}$ from asserting its copyright to prevent Armstrong from reproducing the exhaust pipe design.

Armstrong lost both at the High Court and the Court of Appeal. Lord Bridge in the House of Lords articulated two policy considerations: first, that the owner of a car must be entitled to do whatever is necessary to keep it in running order and to effect whatever repairs may be necessary in the most economical way possible. He found that 'it is a right inherent in the ownership of the car itself' and 'to curtail or restrict the owner's right to repair in any way may diminish the value of the car'. ${ }^{74}$ Secondly, he observed that BL had already enjoyed the primary benefit which their copyright protected when they sold cars fitted with exhausts based on their copyright drawings. To allow them to enforce their copyright to maintain a monopoly for themselves and their licensees in the supply and replacement of exhausts would detract from the car owners' rights and, at least potentially, the value of their cars. ${ }^{75}$ The Court did not articulate specifically that there was a public interest in not enforcing BL's

\footnotetext{
72 ibid [79]-[81].

73 [1986] 1 All ER 850, 854.

74 [1986] 1 All ER 850, 861.

75 ibid 862.
} 
copyright, but it enumerated these policy reasons why BL could not assert its copyright.

It was Lord Hoffmann in Canon Kabushiki Kaisha v Green Cartridge Co (Hong Kong) Ltd ${ }^{76}$ who observed that British Leyland was neither founded on property nor on contract, but on an overriding principle of public policy; namely, the need to prevent a manufacturer from using copyright to control the market in spare parts. ${ }^{77} \mathrm{He}$ did not refer to s 171(3) CDPA, nor to the case law under it, because the case was before the Privy Council dealing with Hong Kong law. However, in Mars UK Ltd $v$ Teknowledge $L t d,{ }^{78}$ which concerned defendants having reverse engineered coin recognition software, Jacob J was willing to accept that there is a public interest defence that applies to cases of repair. But on the facts, he held that it did not meet the test of 'no right-thinking member of society would quarrel with the result'. ${ }^{79}$ Many instances of licence to repair are codified, with some of the provisions enacted because of British Leyland. Accordingly, in Mars, Jacob J held that he could not rely on s 171(3) to override statutory exceptions specific to computer programs in the CDPA. ${ }^{80}$ Commentators argue that the spare parts exception may no longer exist under UK copyright law. ${ }^{81}$ However, the codification does not take away the powers of the courts in circumstances not covered by the statutes.

The foregoing discussion reveals that the courts have approached public interest more conservatively than ambitiously. More important to our discussion is whether such conservatism sits well with the three-step test. Since there are no guidelines for the exercise of the courts' power, the section below takes a retrospective look at whether the courts comply with the test in the subtext, and whether following the test could have led to better results in some cases.

\subsection{Courts' Interpretation of Public Interest and the Three-step Test}

The courts have defined 'certain special cases' with due care, in confining the findings of fact and law to the circumstances of the case.

\footnotetext{
76 [1997] AC 728.

77 ibid 737.

78 [1999] EWHC 226 (Pat).

79 ibid [23], relying on his own ruling in Yelland (n 57) 247.

80 ibid [18]-[19]. Software-specific exceptions are in CDPA, ss 50A-50C.

81 Gavin Llewellyn, 'Does Copyright Recognise a Right to Repair?' [1999] EIPR 596, 599.
} 
Even when the public interest exception came into its own without being overshadowed by confidentiality, such as in Beggars and SCI, the case was well defined within the facts of that case. Spare parts cases, in any event, apply to a very specific scenario, as described above. Regarding the conflict with the normal exploitation of the work, the public interest defence was successful only in Lion, Beggars, SCI and British Leyland. In Lion (internal correspondence) and SCI (undercover video footage), the work did not have any prospect of being exploited by its copyright owner, either because of the nature of the content or because the copyright owner was not in the business of exploiting it.

In Beggars, the video footage could have been economically exploited by its copyright owner. However, the implied licence in favour of the defendants to use the footage in a documentary extended only to its uninterrupted broadcast by denying a preliminary injunction, leaving the copyright owner to a remedy in damages. ${ }^{82}$ Therefore, by pursuing a claim in damages, the copyright owner could have obtained the economic value of the very broadcast that was allowed by the refusal of the injunction. Indeed, the Court refused to allow the defendants to make further use of the footage, limiting the licence to the broadcast sought to be stopped by the injunction, and to the use already made. ${ }^{83}$ Therefore, the Court's enforcement of public interest did not interfere with the normal exploitation of the work.

Had Beggars proceeded to trial and the Court had to decide whether to grant damages, then it would have been essential to read normativity into normal exploitation in asking whether such exploitation should be allowed to interfere with objectives such as the public's right to know and be educated about issues of public health. It may have been difficult for the Court to deny damages because of the difficulty in stretching the normative aspect of normal exploitation to this extent.

Although reading public interest into remedies is a practical approach in some cases, the scope of $\mathrm{s} 171(3)$ is by no means limited to remedies. ${ }^{84}$ The effect of British Leyland was to permit Armstrong to continue to use BL's designs without having to pay any compensation, although BL was exploiting these designs. However, the normative need for the owners of chattels to have access to economical and efficient supply of spare parts for repair was regarded much more highly than the

\footnotetext{
An approach supported in Ashdown [2001] EWCA Civ 1142 [46].

Beggars (n 51) 372-3.

84 Burrell (n 10) 402; Sims (n 10) 341.
} 
need for economic exploitation of copyright in the design. It is debatable whether the normative aspect of normal exploitation extends this far.

In cases like Beloff and Ashdown (minutes), and Yelland (CCTV photos), the possibility of independent exploitation of the work at issue was very low. Thus, in these cases, the courts would not have fallen foul of the second step, even if they had upheld the public interest defence.

As for the balancing exercise required to assess the prejudice to the legitimate interests, the interests of the public in Lion, Beggars, SCI and British Leyland, were far more significant than those of the copyright owners, requiring the balance to tip in favour of the public interest. In Yelland and Ashdown, the public interest in seeing the actual CCTV photos or reading the minutes verbatim could have been better balanced.

In summary, courts have not overstepped the test. On the other hand, there is still sufficient room in the third step for the courts to expand considerations of public interest in the balancing exercise. If the courts had taken appropriate guidance from the three-step test, better results may have been achieved.

\section{PUBLIC INTEREST AND EU COPYRIGHT LAW}

Regardless of the impact of Brexit on UK law, the lesson for excessively formalistic copyright law such as EU copyright law may lie in supplementing the exhaustive list with an additional open-ended provision that allows the courts to arrive at a fair balance when no other exception applies. Even if the courts in member states end up ruling differently, the CJEU as final arbiter can bring about some harmony. There may be a concern that the courts of each member state will adopt its own interpretation, resulting in limitations and exceptions that are divergent from each other. However, certainty need not be compromised to achieve flexibility. Member states will likely refer cases to the CJEU for interpretation, which will eventually lead to a pan-EU jurisprudence on the interpretation of the test that the CJEU approves. Arguably, $G S$ Media $v$ Sanoma $^{85}$ can be read as the CJEU's exercise of powers to restrict or prevent copyright enforcement in public interest. The Court acknowledges that a person hyperlinking to content which has not been placed on the internet with the consent of the copyright owner does amount to communication to the public. But if such person does not pursue profit and does not know or has no reason to believe that the

85 Case C-160/15 GS Media BV v Sanoma Media Netherlands BV [2016] WLR(D) 477. 
content was infringing (innocent users, for short), then the communication is not with the full knowledge of the consequences, and therefore, does not infringe Article 3(1) Infosoc Directive. ${ }^{86}$ Although the Court fashions it as an interpretation of Article 3(1) itself, it is possible to view this from the perspective of the innocent users who benefit from hyperlinking without liability.

The decision clearly refers to freedom of expression and information under Article 11 of the Charter and the pivotal role played by the internet. ${ }^{87}$ It is clear that the public interest in protecting free speech is at the heart of the circuitous reasoning of the court. Instead of interpreting Article 3(1) in an artificial manner, the Court's decision to allow innocent users to hyperlink to infringing content can be read as an instance where the Court restricts copyright enforcement to achieve the public interest in free speech. Since no other statutory limitation or exception enumerated in the Infosoc Directive applies in this case (as the innocent users could be linking for any reason beyond criticism, review or quotation, or no reason at all), public interest captures these considerations outside of the existing framework to achieve a fair result in this case. This makes for a more coherent reasoning for the outcome in $G S$ Media, and one that is supported by the fundamental principles of EU law, namely freedom of expression and the public interest.

\footnotetext{
86 ibid [46]-[51].

87 ibid [45].
} 